\title{
Discovery and paleoenvironmental implications of a Zoophycos-group trace fossil (?Echinospira) from the Middle Pennsylvanian Sydney Mines Formation of Nova Scotia
}

\author{
Duncan McIlroy ${ }^{1}$ And Howard Falcon-LAnG ${ }^{2 *}$ \\ 1. Department of Earth Sciences, Memorial University of Newfoundland, St. John's, Newfoundland, \\ A1B 3X5, Canada <dmc@esd.mun.ca> \\ 2. Department of Earth Sciences, University of Bristol, Bristol BS8 1RJ, UK <howard.falcon-lang@bris.ac.uk> \\ ${ }^{*}$ Corresponding author
}

Date received: 18 October 2005 I Date accepted: 3 February 2006

\begin{abstract}
The discovery of a Zoophycos-group trace fossil questionably attributed to Echinospira is reported from the Middle Pennsylvanian Sydney Mines Formation of Nova Scotia. Zoophycos-group trace fossils are composed of a central axis from which helicoidally arranged sheets of spreite emanate, giving the appearance of stacked cones. Such traces are commonly reported from marine paleoenvironments throughout the Phanerozoic. This occurrence, the first of its kind in the Maritimes Basin, provides further evidence for marine influence during the deposition of these dominantly terrestrial coal-bearing successions.
\end{abstract}

\section{RÉSUMÉ}

On signale la découverte d'un ichnofossile du groupe Zoophycos rattaché de façon douteuse à Échinospira dans la formation du Pennsylvanien moyen de Sydney Mines, en Nouvelle-Écosse. Les ichnofossiles du groupe Zoophycos sont constitués d'un axe central duquel émanent des feuilles de spréite disposées de façon héliocoïdale leur conférant l'aspect de cônes étagés. Ces ichnofossiles sont communément signalés dans les paléoenvironnements marins du Phanérozoïque. La présence de cet ichnofossile particulier, premier du genre dans le bassin des Maritimes, fournit une autre preuve de l'influence marine pendant la sédimentation de ces successions carbonifères en prédominance terrestres.

[Traduit par la rédaction]

\section{INTRODUCTION}

The Middle Pennsylvanian Sydney Mines Formation is a $520 \mathrm{~m}$-thick unit of the Maritimes Basin of Atlantic Canada (Gibling et al. 2004). This dominantly terrestrial paleotropical succession represents deposition on well-drained alluvial plain, poorly drained coastal plain and open water environments (Gibling and Bird 1994). Open water facies, the focus of this study, typically comprise less than $5 \%$ of the stratal thickness, and include metre thick bituminous limestone beds that may extend for tens of kilometres, as well as grey shales, and sandstone bodies (Gibling and Kalkreuth 1991).

Sedimentological and paleontological data suggest that the open water facies formed in a marine-influenced water body. Indicators of marine influence include high sulphur coals bracketing coastal plain strata (Hacquebard and Donaldson 1969), agglutinated foraminifera (Wightman et al. 1994), glaucony (Batson and Gibling 2002), and acritarchs (T.K. Dimitrova, personal communication, 2005). Faunal assemblages are, in general, similar to those of European marine bands (Calver 1968), but are conspicuously lacking in stenohaline elements such as goniatites; collectively, data suggest brackish salinities (Calder 1998).

The extensive, shallow, brackish water bodies inferred from the open water facies are interpreted as the product of an epicontinental sea, perhaps partly analogous to the modern Baltic Sea (Falcon-Lang 2005). The restricted micro-tidal sea (Wells et al. 2005) repeatedly flooded the Maritimes Basin during eustatic highstands, with transgressions developing diachronously in a westerly direction from the Russian Platform and through the North Variscan Basin in Germany (Dallmeyer et al. 1995; Opluštil 2005). Salinity generally decreased in a westerly 
direction (Hampson et al. 1999) consistent with the brackish salinities inferred for the Maritimes Basin.

Here we describe a Zoophycos-group trace fossil from the Sydney Mines Formation. Traces of this group, which range from Cambrian to Recent in marine strata, are conical structures with radiating limbs emanating from a central axis. They are one of the most commonly recorded trace fossils owing to their large size and distinctive morphology. The radial portion of the burrow bears spreite that may be radial in the case of Zoophycos proper or may be within radiating Ushaped Rhizocorallium-like limbs in Echinospira Girotti 1970. Zoophycos-group trace fossils are most commonly found in
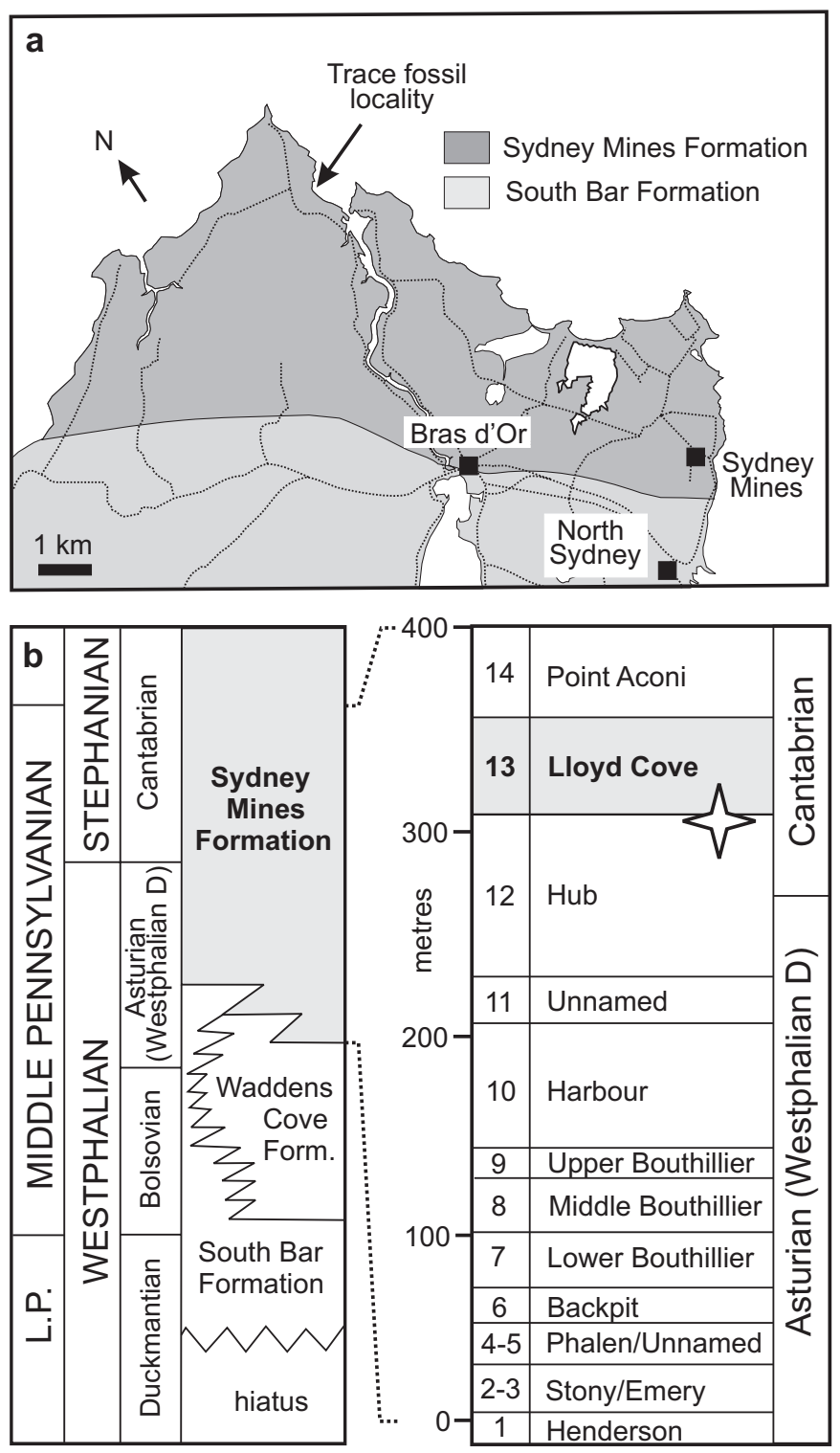

Fig. 1. Geological setting: (a) location of trace-fossil bearing unit, Boularderie Island, Cape Breton, Nova Scotia; and (b) stratigraphic position of the trace-fossil bearing unit (indicated by star) within the Middle Pennsylvanian Sydney Mines Formation, cyclothems of which are indicated to the right. mud-rich facies from below fair weather wave base to deep water basin floor environments (Ekdale 1985).

This is the first time that a Zoophycos-group fossil has been recorded from the entire Maritimes Basin as far as we are aware. Trace fossils are important indicators of marine and/or tidal influences in dominantly terrestrial Pennsylvanian successions (Eagar et al. 1985; Archer et al. 1994, 1995; Brettle et al. 2002). The occurrence of a Zoophycos-group trace fossil in the Sydney Mines Formation lends further strong support for marine-influence during the deposition of this unit.

\section{GEOLOGICAL CONTEXT}

The Zoophycos-group trace-fossil was discovered in a sea-cliff section, about $550 \mathrm{~m}$ south of High Cape, on the western side of the Little Bras D'Or Channel, Boularderie Island, Cape Breton, Nova Scotia (Fig. 1a; latitude 46 ${ }^{\circ} 19^{\prime} 05^{\prime \prime}$; longitude $60^{\circ} 17^{\prime} 24^{\prime \prime}$ ). The trace fossil was located within a sandstone body $7 \mathrm{~m}$ below the base of the lower leaf of the Lloyd Cove Seam of the Sydney Mines Formation (Fig. 1b; Gibling et al. 2004). This interval lies approximately $40 \mathrm{~m}$ above the Asturian (formerly Westphalian D)-Cantabrian substage boundary (Cleal et al. 2003) and is therefore assigned to the uppermost part of the Middle Pennsylvanian Series (Heckel and Clayton 2005).

The succession containing the Lloyd Cove seam represents a transgressive systems tract formed during sustained baselevel rise (Gibling et al. 2004). Agglutinated foraminifera with a brackish water affinity have been recognized throughout this succession, including the interval relevant to the present study (Gibling and Wightman 1994). The succession is interpreted as resulting from deposition in a marine-influenced coastal plain on which long-lived peat mires periodically developed.

The trace-fossil-bearing unit is a very fine-grained, ero-

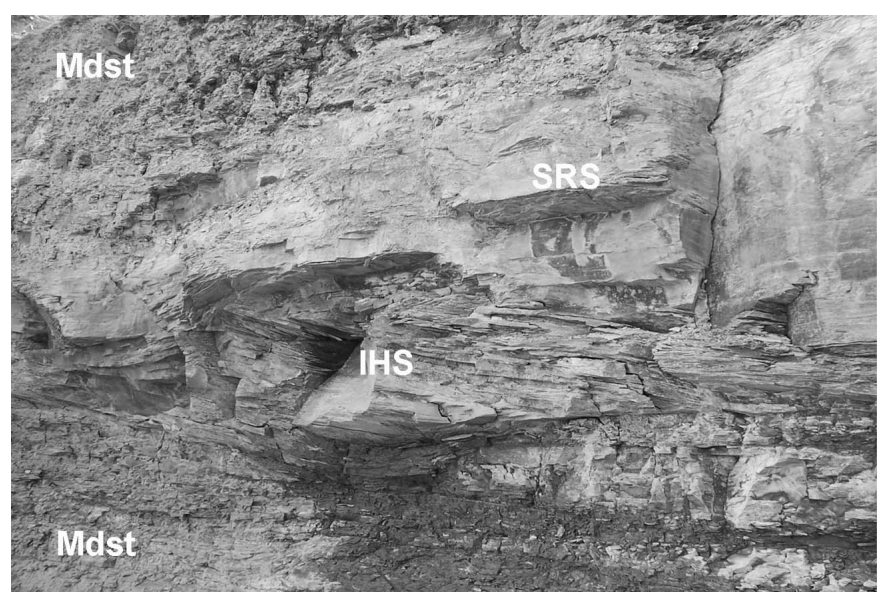

Fig. 2. The trace-fossil-bearing sandstone body, positioned $7 \mathrm{~m}$ below the Lloyd Cove seam, $500 \mathrm{~m}$ south of High Cape, Boularderie Island, Cape Breton. Key: IHS, Inclined Heterolithic Stratification; SRS, Symmetrically-Rippled Sandstone; Mdst, Grey Mudstone. 
sive-based sandstone body, 2.5-3 m thick (Fig. 2). A basal $0.8 \mathrm{~m}$-thick unit contains inclined heterolithic stratification (IHS) with millimetre-thick mudstone laminations. Towards the upper part of the body, bimodal cross-lamination is present and, where locally exposed in plan view, some surfaces show symmetrical ripple marks (SRS). The unit is tentatively interpreted as an estuarine deposit, with the lower inclined channel body formed in a meandering coastal creek subject to weak tidal currents, and the upper strata originating in a tidal flat setting. The trace fossil was found in a large fallen sandstone block on the foreshore and its original horizon within the sandstone body exposed in the sea-cliffs could not be precisely ascertained; however, it probably originated from the symmetrically rippled tidal flat deposits. Due to its large size, the specimen could not be collected.

\section{DESCRIPTION AND AFFINITY OF THE TRACE FOSSIL}

The specimen is a large ( $245 \mathrm{~mm}$ radius), incompletely preserved, roughly conical structure on the upper surface of a sandstone bed (Fig. 3a). The centre of the cone is marked by a vertical cylinder $16 \mathrm{~mm}$ in diameter. Radiating from the apex of the cone are ridges that are nearly uniform in width $(6-10 \mathrm{~mm})$ and commonly show branching in the most distal quarter.

The branches are organized in clusters (1-15 in Fig. 3b) that are typically composed of groups of two or three related branches, with a maximum of six related branches seen in cluster 14. In most cases, crosscutting is such that branches inferred to have been produced later are clockwise of the earlier-produced limbs. The exceptions to this are seen in cluster 5 (Fig. 3b), which is characterized by an unusually short first branch, and in cluster 10 where subsequent crosscutting is in an anticlockwise direction. Furthermore, it seems that the clusters were also usually generated in a clockwise direction, though clusters 6-8 appear to have been emplaced in an anticlockwise direction (Fig. 3b). Detailed examination of the branches show them to be composed of a lighter-coloured, depressed, marginal rim, surrounding a central, raised, clay-rich region with faint U-shaped impressions that are convex distally. The systematic addition of branched radiating features, as well as their nearly uniform width, eliminates the possibility that the structure was a sand volcano produced by dewatering of sand at the sea floor.

The individual branches of the trace fossil bear a strong resemblance to long narrow examples of the sub-horizontal U-shaped spreiten burrow Rhizocorallium irregulare Mayer 1954, which is known from Late Paleozoic and Mesozoic rocks. Unlike Rhizocorallium irregulare, the present structure contains many associated U-burrows that branch and show crosscutting, are organized in a conical structure, and are related to a central cylindrical feature. In this way the structure is most similar to the Zoophycos-group trace fossils (sensu Uchman 1995; equivalent to the Alectoruridae of Schimper and Schenk 1879-85).

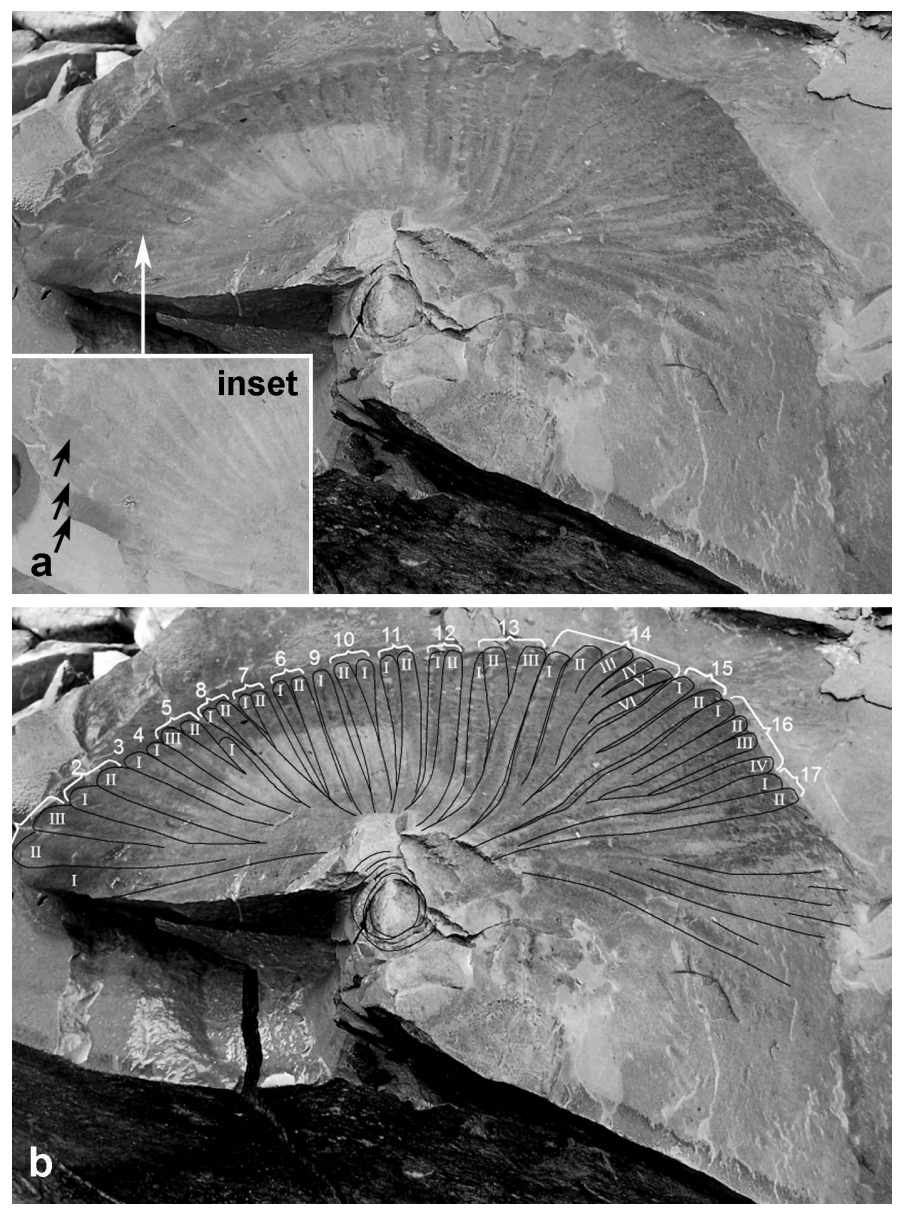

Fig. 3. The trace-fossil specimen: (a) uninterpreted photograph of Zoophycos-group trace fossil; inset shows detail of spreite (arrowed); and (b) interpreted photograph showing clusters of branches (1-17) with dominantly clockwise crosscutting patterns $(\mathrm{I}-\mathrm{V})$.

The whole structure appears to have been produced by systematic sediment processing by an infaunal deposit feeder. During feeding, the trace maker produced a U-shaped burrow that it extended to create the long narrow limbs. Partial retraction followed by continued sediment processing would then have produced the distal branching to create the branch clusters. More complete retraction of more than $50 \%$ of the length of the U-burrow initiated a new burrow cluster adjacent to the previous one, and sometimes overlapped it.

Such radiating patterns of U-burrows were first described from Zoophycos-group trace fossils from the Quaternary of New Zealand (Ekdale and Lewis 1991). The present material most closely resembles Echinospira Girotti 1970, described from the Miocene of Italy, which shows self crossing in the type and subsequent material (Ekdale and Lewis 1991; Uchman 1995; Uchman and Demírcan 1999). In contrast, primary successive branching is clearly present in our material (Fig. 3b). Some comparisons may also be made with Zoophycos rhodensis Bromley and Hanken 2003, described from the Pliocene of 
Greece, though our material lacks the minor lamellae of that material and does not appear pelleted. Although our material is similar to these Cenozoic forms, it is considerably older and does not clearly fit within any of the existing ichnotaxa.

\section{CONCLUSIONS}

While the detailed taxonomic affinity of the present specimen is ambiguous, it can be confidently assigned to the Zoophycos-group trace fossils (equivalent to the Alectoruridae), which have a paleoenvironmental range that is exclusively marine (Uchman 1995). Zoophycos-group trace fossils are commonly found in association with marine flooding surfaces in the Pennsylvanian of the United Kingdom (?Echinospira isp., McIlroy unpublished data) and rarely in the Mesozoic (MacEachern and Burton, 2000). The present fossil provides further evidence for the periodic extension of a seaway from the Russian Platform westwards into the Maritimes Basin during Pennsylvanian times (Falcon-Lang 2005). Additional in situ specimens are needed to constrain the precise sedimentological and sequence stratigraphic context of the Sydney Mines ?Echinospira.

\section{ACKNOWLEDGEMENTS}

Howard Falcon-Lang acknowledges a NERC Fellowship (NER/I/S/2001/00738) held at the University of Bristol and a Paleontology Grant (2001) from the Nova Scotia Museum. Duncan McIlroy is Canada Research Chair in Petroleum Science and thanks the Canada Research Chair fund and NSERC for support of his research. We thank Deborah Skilliter and David Keighley for their insightful reviews, and Rob Fensome for efficiently overseeing the editorial process.

\section{REFERENCES}

Archer, A.W., Feldman, H.R., Kvale, E.P., \& Lanier, W.P. 1994. Comparison of drier- to wetter-interval estuarine roof facies in the Eastern and Western Interior coal basins, USA. Palaeogeography, Palaeoclimatology, Palaeoecology, 106, pp. 171-185.

Archer, A.W., CAlder, J.H., Gibling, M.R., NaYlor, R.D., ReID, D.R., \& Wightman, W.G. 1995. Invertebrate trace fossils and agglutinated foraminifera as indicators of marine influences within the classic Carboniferous section at Joggins, Nova Scotia, Canada. Canadian Journal of Earth Sciences, 32, pp. 2027-2039.

BATson, P.A., \& Gibling, M.R. 2002, Architecture of channel bodies and paleovalley fills in high-frequency Carboniferous sequences, Sydney Basin, Atlantic Canada. Bulletin of Canadian Petroleum Geology, 50, pp. 138-157.

Brettle, M.J., McIlroy, D., Elliott, T.E., Davis, S.J., \& Waters, C.N. 2002. Identifying cryptic tidal influences within deltaic successions: an example from the Marsdenian (Namurian) interval of the Pennine Basin, UK. Journal of the Geological Society of London, 159, pp. 379-391.

Bromley, R.G., \& Hanken N.-M. 2003. Structure and function of large, lobed Zoophycos, Pliocene of Rhodes, Greece. Palaeogeography, Palaeoclimatology, Palaeoecology, 192, pp. 79-100.

Calder, J.H. 1998. The Carboniferous evolution of Nova Scotia. In Lyell: the past is the key to the present. Edited by D.J. Blundell and A.C. Scott. Geological Society of London, Special Publications, 143, pp. 261-302.

CALVER, M.A. 1968. Invertebrate faunas. In Coal and coalbearing strata. Edited by D. Murchison and T.S. Westoll. Oliver \& Boyd, Edinburgh, pp. 147-177.

Cleal, C.J., Dimitrova, T.K., \& Zodrow, E.L. 2003. Macrofloral and palynological criteria for recognising the Westphalian-Stephanian boundary. Newsletter on Stratigraphy, 39, pp. 181-208.

Dallmeyer, R.D., Franke W., \& Weber, K. (editors) 1995. Pre-Permian geology of Central and Eastern Europe. Springer-Verlag, Berlin, $609 \mathrm{p}$.

EAgER, R.M.C., Baines, J.G., Collinson, J.D., Hardy, P.G., OкоLо, S.A., \& Pollard, J.E. 1985. Trace fossils and their occurrence in the Silesian (mid-Carboniferous) deltaic sediments of the central Pennine Basin, England. In Biogenic structures, their use in interpreting depositional environments. Edited by H.A. Curran. SEPM Special Publication, 35 , pp. 99-149.

Ekdale, A.A. 1985. Paleoecology of marine endobenthos. Palaeogeography, Palaeoclimatology, Palaeoecology, 50, pp. 63-81.

Ekdale, A.A., \& Lewis, D.W. 1991. The New Zealand Zoophycos revisited: morphology, ethology, and paleoecology. Ichnos, 1, pp. 183-194.

FALCON-LANG, H.J. 2005. Small cordaitalean trees in a marine-influenced coastal habitat in the Pennsylvanian Joggins Formation, Nova Scotia, Canada. Journal of the Geological Society of London, 162, pp. 485-500.

Gibling, M.R., \& BiRD, D.J. 1994. Late Carboniferous cyclothems and alluvial paleovalleys in the Sydney Basin, Nova Scotia. Geological Society of America Bulletin, 106, pp. 105-117.

Gibling, M.R., \& Kalkreuth, W.D. 1991. Petrology of selected carbonaceous limestones and shales in Late Carboniferous coal basins of Atlantic Canada. International Journal of Coal Geology, 17, pp. 239-271.

Gibling, M.R., \& Wightman, W.G. 1994. Palaeovalleys and protozoan assemblages in a Late Carboniferous cyclothem, Sydney Basin, Nova Scotia. Sedimentology, 41, pp. 699-719.

Gibling, M.R., SAunders, K.I., Tibert, N.E., \& White, J.A. 2004. Sequence sets, high-accommodation events and the coal window in the Carboniferous Sydney Coalfield, Atlantic Canada. In Coal-bearing strata: sequence stratigraphy, paleoclimate, and tectonics. Edited by J. Pashin and R.A. 
Gastaldo. American Association of Petroleum Geologists Studies in Geology Series, 51, pp. 169-198.

GirotTI, O. 1970. Echinospira pauciradiata g. n. sp. n., ichnofossil from the Serravallian-Tortonian of Ascoli Pienco (central Italy). Geologica Romana, 9, pp. 59-62.

HaCquebard, P.A., \& Donaldson, J.R. 1969. Carboniferous coal deposition associated with floodplain and limnic environments in Nova Scotia. In Environments of coal deposition. Edited by E.C. Dapples and M.E. Hopkins. Geological Society of America Special Paper 114, pp. 143-191.

Hampson, G., Stollhofen, H., \& Flint, S. 1999. A sequence stratigraphic model for the Lower Coal Measures (Upper Carboniferous) of the Ruhr district, northwest Germany. Sedimentology, 46, pp. 1199-1231.

Heckel, P., \& Clayton, G. 2005. Official names for the Carboniferous System. Geology Today, 21, pp. 213-214.

MacEachern, J.A., \& Burton, J.A. 2000. Firmground Zoophycos in the Lower Cretaceous Viking Formation, Alberta: a distal expression of the Glossifungites Ichnofacies. Palaios, 15, pp. 387-398.

MAYER, E. 1954. Neue Beobachtungen und Lebenspurren aus dem underen Hauptrumskalk (Trochienkalk) von Weisloch. Neues Jahrbuch für Geologie und Paläontologie, Abhandlungen, 2, pp. 223-229.

OpLušTiL, S. 2005. Evolution of the middle Westphalian river valley drainage system in central Bohemia (Czech Republic) and its palaeogeographic implications. Palaeogeography, Palaeoclimatology, Palaeoecology, 222, pp. 223-258.

SCHIMPER, W.P., \& SCHENK, A. 1879-85. Palaeophytology. In Handbuch der Palaeontologie, Abteilung 2. Edited by K.A. von Zittel. Oldenbourg, Munich and Leipzig, pp. 1-958.

Uchman, A. 1995. Taxonomy and palaeoecology of flysch trace fossils: the Marnoso-arenacea Formation and associated facies (Miocene, northern Apennines, Italy). Beringeria Würzburger Geowissenschaft, 25, pp. 1-115.

Uchman, A., \& Demírcan, H. 1999. A Zoophycos group trace fossil from Miocene Flysch in southern Turkey: evidence for a U shaped causative burrow. Ichnos, 6, pp. 251-259.

Wells, M.R., Allison, P.A., Piggott, M.D., Pain, C.C., Hampson, G.J., \& De Oliviera, C. R. E. 2005. Large sea, small tides: the Late Carboniferous seaway of NW Europe. Journal of the Geological Society of London, 162, pp. 417-420.

Wightman, W.G., Scott, D.B., Medioli, F.S., \& Gibling, M.R. 1994. Agglutinated foraminifera and thecamoebians from the Late Carboniferous Sydney Coalfield, Nova Scotia: palaeoecology, palaeoenvironments and palaeogeographic implications. Palaeogeography, Palaeoclimatology, Palaeoecology, 106, pp. 187-202.

Editorial responsibility: Robert A. Fensome 
